\title{
Rumen Lipopolysaccharide and Inflammation During Grain Adaptation and Subacute Ruminal Acidosis in Steers
}

\author{
G. N. Gozho, D. O. Krause, and J. C. Plaizier ${ }^{1}$ \\ Department of Animal Science, University of Manitoba, Winnipeg, MB, Canada R3T 2N2
}

\begin{abstract}
Three rumen-fistulated Jersey steers were gradually adapted to a wheat-barley concentrate over a 4-wk period. Adaptation steps consisted of four 1-wk periods during which steers were fed diets with forage-to-concentrate (F:C) ratios of 100:0, 79:21, 59:41, and 39:61. The forage consisted of chopped hay $(\mathrm{CH})$, and the concentrate consisted of pelleted concentrate containing $50 \%$ ground wheat and $50 \%$ ground barley. Steers were fed the all-forage diet ad libitum during wk 1. Feed offered in wk 2 to 4 was kept constant at the ad libitum intake during wk 1 . On $2 \mathrm{~d}$ that were set $3 \mathrm{~d}$ apart during wk 5, subacute ruminal acidosis (SARA) was induced in the steers by feeding a diet with an $\mathrm{F}$ :C ratio of $24: 76$ by offering them $0.9 \mathrm{~kg}$ of $\mathrm{CH}$ at $0900 \mathrm{~h}$ followed by 2 meals of $3.0 \mathrm{~kg}$ each of wheat-barley pellets (WBP) at $1100 \mathrm{~h}$ and $1300 \mathrm{~h}$ and $0.9 \mathrm{~kg}$ of $\mathrm{CH}$ at $1700 \mathrm{~h}$, to depress rumen $\mathrm{pH}$ for at least $3 \mathrm{~h} / \mathrm{d}$ below 5.6. The average concentrate inclusion for the SARA induction diet was $76 \pm 10 \%$ DM. During stepwise adaptation, time with $\mathrm{pH}$ below 5.6 increased to an average of 121 $\mathrm{min} / \mathrm{d}$ when the steers were consuming a diet containing $61 \% \mathrm{DM}$ as WBP. Dietary inclusion of WBP at the rate of $76 \% \mathrm{DM}$ induced SARA because the steers spent an average of $219 \mathrm{~min} / \mathrm{d}$ with $\mathrm{pH}$ below 5.6. The free ruminal lipopolysaccharide (LPS) concentration increased from 6,310 endotoxin units $(\mathrm{EU}) / \mathrm{mL}$ with the all-forage diet to $18,197 \mathrm{EU} / \mathrm{mL}$ with the $61 \%$ concentrate diet. The ruminal LPS concentration increased to $26,915 \mathrm{EU} / \mathrm{mL}$ when SARA was induced. Serum haptoglobin increased from $0.53 \mathrm{mg} / \mathrm{mL}$ when steers were on the all-forage diet to $1.90 \mathrm{mg} / \mathrm{mL}$ with the $61 \%$ concentrate diet and were not increased further by inducing SARA. The serum amyloid-A concentration was not affected by increasing dietary concentrate during stepwise adaptation to the concentrate, but increased from 71 to $163 \mu \mathrm{g} / \mathrm{mL}$ when SARA was induced. A gradual increase in dietary concentrate so that the $\mathrm{F}: \mathrm{C}$ ratio decreased to 39:61 resulted in increased ruminal LPS
\end{abstract}

Received September 17, 2005.

Accepted June 7, 2006.

${ }^{1}$ Corresponding author: plaizier@ms.umanitoba.ca concentrations. Subsequent induction of SARA further increased ruminal LPS and activated an inflammatory response.

Key words: subacute ruminal acidosis, lipopolysaccharide, serum amyloid-A, haptoglobin

\section{INTRODUCTION}

The following indicators of subacute ruminal acidosis (SARA) appear in the literature: daily episodes of low rumen $\mathrm{pH}$ below 5.6 for at least $3 \mathrm{~h}$ (Cooper et al., 1999; Gozho et al., 2005), erratic feed intake, diarrhea, subcutaneous abscesses not associated with injections, loss of body condition, and laminitis (Nordlund et al., 1995; Nocek, 1997). Apart from rumen $\mathrm{pH}$, these signs are not specific to SARA and individually are of limited diagnostic value. However, if the clinical signs, production records, dietary characteristics, and rumen $\mathrm{pH}$ are considered together on a herd basis, SARA can be diagnosed (Nordlund et al., 2004).

One of the greatest impediments to the diagnosis of SARA is the measurement of rumen $\mathrm{pH}$ because of the difficulty in obtaining accurate data under field conditions. Therefore, only limited information on its prevalence is available. A survey on 15 dairy farms in Wisconsin showed the presence of SARA in 19\% of early-lactation cows and $26 \%$ of midlactation cows (Garrett et al., 1997). Another survey on 14 dairy farms in Wisconsin detected SARA in $20.1 \%$ of early- and peak-lactation cows (Oetzel et al., 1999). Dairy cows at high risk of developing SARA include those in the transition period, those on high DM consumption, and those that are subjected to a high degree of variability in ration composition and meal patterns (Stone, 2004).

Suddenly switching cattle from a high-forage to a high-starch diet results in decreases in rumen $\mathrm{pH}$ that are characteristic of SARA because VFA accumulate in the rumen (Goad et al., 1998). The increase in nonstructural carbohydrates in the diet of cattle during gradual grain adaptation results in microbiological changes in the rumen. Key among the changes is the increase in lactate-utilizing bacteria such as Megasphaera elsdenii (Counotte et al., 1981). These are relatively slow-growing bacteria found in low numbers in ruminants fed high-forage diets, and they increase in number only 
when lactate is a major end product of rumen fermentation. If the rate of concentrate inclusion in the diet is higher than the rate at which lactate-utilizing bacteria can increase, then lactic acid accumulates in the rumen and depresses rumen $\mathrm{pH}$ more drastically than similar amounts of VFA (Owens et al., 1998). Fluctuation in the numbers of lactic acid-producing and lactic acidutilizing bacteria occur even in grain-adapted cattle during the course of the day because of variation in nutrients and the range in substrate preference of different microbial species (Dijkstra et al., 2002). However, unlike in cattle adapted to forage diets, the lactate-utilizing bacteria are present at high numbers and consume lactate quickly (Mackie and Gilchrist, 1979).

Data on bacteriological changes (Mackie et al., 1978; Mackie and Gilchrist, 1979) and changes in ruminal LPS (Andersen et al., 1994) have all been obtained in experiments in which acute ruminal acidosis was induced. Subacute ruminal acidosis is the more economically important form of acidosis in dairy cattle (Stone, 2004) and there is a need for research that increases our understanding of its etiology. Additionally, the physiological response to SARA may differ from that observed with acute acidosis because the decrease in rumen $\mathrm{pH}$ is not as severe as that experienced with acute acidosis. It is also possible that changes in ruminal LPS concentrations and the subsequent immune response may differ when SARA is induced in cattle previously adapted to an all-forage diet vs. after gradual adaptation to high-concentrate diets.

Inducing SARA by abruptly introducing a high-grain diet to steers previously adapted to an all-forage diet increased ruminal LPS, serum amyloid-A (SAA), and haptoglobin (Hp) concentrations (Gozho et al., 2005). We hypothesized that the immune and microbial response would differ if SARA were induced in cattle previously adapted to concentrate because the predominant bacteria species are believed to differ (Nagaraja et al., 1978). Therefore, the objective of this study was to determine the effect of gradual stepwise adaptation to concentrate and subsequently inducing SARA on the ruminal LPS concentration and inflammatory response. The importance of ruminal LPS stems from the fact that high ruminal LPS concentrations may predispose cattle to immunological perturbations, which may signify the onset of subclinical disease such as rumenitis.

\section{MATERIALS AND METHODS}

\section{Animals and Diets}

Three adult ruminally fistulated Jersey steers with average body weight of $678 \pm 16 \mathrm{~kg}$ (mean $\pm \mathrm{SD}$ ) were adapted to a wheat-barley pellet (WBP) diet over a 4-
Table 1. Chemical composition for wheat-barley pellets (WBP) and chopped hay $(\mathrm{CH})$

\begin{tabular}{lcc}
\hline Item & CH & WBP \\
\hline DM, \% & 89.2 & 92.5 \\
CP, \% of DM & 10.9 & 15.5 \\
NDF, \% of DM & 64.0 & 17.6 \\
ADF, \% of DM & 35.9 & 5.9 \\
NSC, \% of DM & 15.2 & 62.2 \\
Ca, \% of DM & 0.38 & 0.27 \\
P, \% of DM & 0.27 & 0.35 \\
K, \% of DM & 1.93 & 0.56 \\
Mg, \% of DM & 0.20 & 0.16 \\
Na, \% of DM & 0.01 & 0.03 \\
\hline
\end{tabular}

wk period in a time-series experimental design. The pellets were made of $50 \%$ wheat and $50 \%$ barley that was ground and pelleted. The steers were maintained in metabolism crates in the Animal Science Research Unit building at the University of Manitoba, in accordance with the guidelines of the Canadian Council of Animal Care. The room that houses the crates is fitted with the Proportional Environment Control system (model PEC; Phason, Winnipeg, Manitoba, Canada). Ambient temperature in the room was maintained at $15^{\circ} \mathrm{C}$ for the duration of the experiment. The steers were kept indoors from Monday to Friday and were let out into a courtyard for $4 \mathrm{~h}$ to exercise on Saturdays and Sundays. The courtyard was made of bare concrete, and the animals had no access to any other types of feed or grazing during this time.

Steers were initially fed an all-forage diet comprising chopped hay $(\mathbf{C H})$ ad libitum for $7 \mathrm{~d}$. Steers had unlimited access to fresh water and unlimited access to cobalt iodized salt blocks (Sifto Canada Ltd., Mississauga, Ontario, Canada) that contained $99 \% \mathrm{NaCl}, 180 \mathrm{mg} / \mathrm{kg}$ of $\mathrm{I}$, and $120 \mathrm{mg} / \mathrm{kg}$ of Co. The hay was baled in large round bales with a weight of approximately $700 \mathrm{~kg}$ and chopped with a Case/IH model 8610 bale processor (JI Case International, Racine, WI). Analysis of the particle size distribution of the hay using the Penn State Particle Separator (PSPS; Lammers et al., 1996) showed that 27.6 and $23.4 \%$ were retained by the 19 - and 8 $\mathrm{mm}$ PSPS screens, respectively, and that $49.0 \%$ of the hay was not retained by the PSPS screens. The chemical compositions of $\mathrm{CH}$ and WBP are given in Table 1.

After feeding hay ad libitum during wk 1 , intake was kept constant at ad libitum intake of $\mathrm{CH}$ during the stepwise concentrate adaptation steps for $21 \mathrm{~d}$, during which concentrate was increased (on a DM basis) from 0 to 21,41 , and $61 \%$ every $7 \mathrm{~d}$. Limiting intake to ad libitum intake of the $\mathrm{CH}$ diet was designed to prevent erratic feed intake as the inclusion of concentrate increased in the diets. The $\mathrm{CH}$ and WBP were thoroughly mixed and offered to the steers at $0900 \mathrm{~h}$ every day during wk 2 to 4 . In wk 5, SARA was induced in the 
steers by offering them $0.9 \mathrm{~kg}$ (DM basis) of $\mathrm{CH}$ at 0900 $\mathrm{h}$, followed by 2 meals each of $3.0 \mathrm{~kg}$ of WBP at 1100 and $1300 \mathrm{~h}$ and $0.9 \mathrm{~kg}$ of $\mathrm{CH}$ at $1700 \mathrm{~h}$ on Monday and Friday of wk 5. This resulted in a dietary forage-toconcentrate ratio of 24:76 during SARA induction. During the other days of wk 5 , steers were given the $61 \%$ concentrate diet.

Each 7-d period in the first 4 wk during which the WBP level of the diet was increased, as well as the 2 $\mathrm{d}$ in wk 5 in which SARA was induced, constituted separate treatments. Thus, treatments were arranged in a time-series design, and diets with concentrate inclusions of $0,21,41,61$, and $76 \%$ were designated treatments $1,2,3,4$, and 5 , respectively. Weigh backs were determined and sampled for DM determination. Dry matter contents were $89.2 \%$ for $\mathrm{CH}$ and $92.5 \%$ for WBP.

\section{Rumen pH Measurement}

Rumen $\mathrm{pH}$ was measured continuously for two 24-h periods during each week by inserting one Sensorex Combi pH Electrode 450 CD (Sensorex, Stanton, CA) through the cannula into the rumen of each steer as described by Cumby et al. (2001). The electrode was suspended into the ventral sac of the rumen protected by a wire shield and attached to a weight of approximately $0.5 \mathrm{~kg}$. Electrodes were connected to a Jenco digital $\mathrm{pH}$ transmitter, model $691 \mathrm{~N}$ (Jenco Inc., La Jolla, CA). The output of the $\mathrm{pH}$ transmitter was captured by a Monarch DC 5000 data logger (Monarch Instruments, Amherst, $\mathrm{NH}$ ). A pH reading was taken every $60 \mathrm{~s}$ and subsequently stored for further analysis. The continuous ruminal $\mathrm{pH}$ data was summarized for each 24 -h period by calculating the average $\mathrm{pH}$, the amount of time below pH 6 and 5.6, and the area (time $\times \mathrm{pH})$ below $\mathrm{pH} 6$ and 5.6. The position of each $\mathrm{pH}$ electrode was checked daily, and the electrodes and $\mathrm{pH}$ transmitters were calibrated with $\mathrm{pH} 4$ and 7 buffer solutions (Fisher Scientific, Fairlawn, NJ) at least once weekly. Rumen fluid was sampled once per day for $\mathrm{pH}$ measurement and compared with continuous $\mathrm{pH}$ recordings to ensure that the $\mathrm{pH}$ electrodes were recording accurate readings. For wk 1 to 4, electrodes were inserted on Thursday at $0900 \mathrm{~h}$ and were taken out on Saturday at 0900 h. During wk 5, electrodes were inserted on Monday at $0900 \mathrm{~h}$ and taken out on Tuesday $0900 \mathrm{~h}$, then reinserted at $0900 \mathrm{~h}$ on Thursday and removed on Friday at $0900 \mathrm{~h}$.

Rumen fluid samples were collected from each steer into sterile plastic tubes from the ventral sac of the rumen in the area next to the $\mathrm{pH}$ electrode at 0900 , $1200,1500,2100$, and $0300 \mathrm{~h}$ during wk 1 to 4 starting on Thursday morning and ending on Saturday morning. In wk 5 rumen fluid samples were collected for two 24- $\mathrm{h}$ periods so that sampling began on Monday at 0900 $\mathrm{h}$ and ended on Tuesday at $0300 \mathrm{~h}$ for the first 24-h period, and the second 24-h sampling period started on Thursday at $0900 \mathrm{~h}$ and ended on Friday at $0300 \mathrm{~h}$. The rumen fluid samples were processed for subsequent LPS determination as described previously (Gozho et al., 2005). Another rumen fluid sample was collected from each animal into sterile plastic vials with airtight lids at $0900,1200,1500$, and $2100 \mathrm{~h}$ and used immediately to determine total coliform counts. A portion of this second sample was also centrifuged at 1,500 $\times \mathrm{g}$ for $10 \mathrm{~min}$ and the supernatant was stored at $-20^{\circ} \mathrm{C}$ for VFA analysis at a later stage.

\section{Ruminal LPS and VFA Analyses}

The Limulus amoebocyte lysate assay was used to determine LPS concentration (Levin and Bang, 1964). The assay was performed using a 96-well microplate kit (Cambrex Bio Science Walkersville Inc., Walkersville, MD) with absorbance read at $405 \mathrm{~nm}$ using a microplate reader (model 3550; Bio-Rad, Hercules, CA). Detailed procedures for sample preparation and method validation have been described previously (Gozho et al., 2005).

Volatile fatty acids were determined in previously frozen rumen fluid samples. Samples were thawed at room temperature and $1 \mathrm{~mL}$ of a $25 \%$ metaphosphoric acid solution was added to $5 \mathrm{~mL}$ of rumen fluid. The tubes containing the mixture were vortexed and placed in a $-20^{\circ} \mathrm{C}$ freezer for $17 \mathrm{~h}$, after which samples were thawed and centrifuged for $10 \mathrm{~min}$ at 1,500 $\times$ g. Approximately $2 \mathrm{~mL}$ of supernatant was decanted into a clean, dry vial, which was capped and placed into the autosampler device (model 8100; Varian, Walnut Creek, CA). Concentrations of VFA were determined by gas chromatography (model 3400 Star; Varian) using a 1.83-m glass column (model 2-1721; Supelco, Oakville, Ontario, Canada; Erwin et al., 1961). The injector and detector temperatures were set at 170 and 195, with initial and final column temperatures set at 120 and $165^{\circ} \mathrm{C}$, respectively. The runtime was $4 \mathrm{~min}$, followed by a 2 -min thermal stabilization period.

\section{Acute Phase Proteins}

Blood samples were collected twice via extended-use polyurethane catheters (Mila Cath, Mila International, Florence, KY) fitted into the jugular vein of each steer. Samples were collected at 0900 and $2100 \mathrm{~h}$ on the days that rumen $\mathrm{pH}$ was measured (Thursday and Friday for wk 1 to 4 and Monday and Thursday for wk 5). At each blood sampling, and at least once daily, the catheter sites were examined for inflammatory reactions, and catheters were flushed with approximately $15 \mathrm{~mL}$ 
of $0.9 \%$ sterile saline. After each sample collection, 5 $\mathrm{mL}$ of $0.9 \%$ sterile saline containing $50 \mathrm{IU}$ of heparin (Sigma-Aldrich, St. Louis, MO) was infused into the vein to prevent clot formation. Before blood collection, the heparinized saline solution was aspirated along with approximately 10 to $15 \mathrm{~mL}$ of blood and discarded. Two blood samples $(10 \mathrm{~mL})$ were collected into serum and plasma tubes. Serum and plasma were harvested by centrifuging samples at $1,500 \times g$ for $30 \mathrm{~min}$. Haptoglobin and SAA were determined in serum and plasma, respectively, using ELISA Tri-Delta phase range assay kits (Tri-Delta Diagnostics Inc., Morris Plains, NJ; catalog numbers TP-801 and TP-802, respectively) as described by Gozho et al. (2005).

\section{Total Coliform Counts}

Preparation of the chromogenic medium (Escherichia coli/coliform medium, catalog number CM0956; Oxoid Inc., Nepean, Ontario, Canada) was modified to include a step in which $20 \%$ of the distilled water was replaced with clarified rumen fluid. The clarification process for the rumen fluid included centrifuging the rumen fluid at $1,500 \times g$ for $10 \mathrm{~min}$, followed by autoclaving the supernatant at $121^{\circ} \mathrm{C}$ for $15 \mathrm{~min}$. The supernatant was stored at $-20^{\circ} \mathrm{C}$ until required for preparing the medium. The rumen fluid was collected from a fistulated cow fed on a diet comprising $100 \% \mathrm{CH}$. The hay fed to this cow came from the same batch that was used in the experiment.

Buffered peptone water ( $\mathrm{pH}$ 7.2; Difco, Detroit, MI) was prepared according to the manufacturer's instructions. Carbon dioxide gas was bubbled through the buffered peptone water and the chromogenic E. coli/coliform medium immediately after preparation and autoclaving to reduce the oxygen tension (Bryant, 1972). The coliform medium was used for culturing rumen coliform bacteria, whereas the buffered peptone water was used for the serial dilutions of rumen fluid samples prior to inoculation into petri dishes. The chromogenic medium is normally used to differentiate between $E$. coli and other coliforms in cultures produced from food and environmental samples (Frampton et al., 1988).

Using aseptic techniques, $100 \mu \mathrm{L}$ of rumen fluid was inoculated into $900 \mu \mathrm{L}$ of $2 \%$ buffered peptone water in a 2-mL sterile, deep-well plate and thoroughly mixed by aspirating and dispensing the mixture several times and then serially diluted to the appropriate dilution. Sterile pipette tips were used for each dilution. Drop plating was performed and 10 drops of $50 \mu \mathrm{L}$ each were pipetted (Repeater 4780; Eppendorf, Hamburg, Germany) onto modified chromogenic $E$. coli/coliform medium that had been prepared previously and allowed to set. After the drops on the agar had dried, the plates were inverted and incubated at $37^{\circ} \mathrm{C}$ for $18 \mathrm{~h}$. Colonies were manually counted and broadly classified according to color, with purple being designated $E$. coli and pink to brown colonies as other coliforms. The countable dilution was determined as the dilution that gave 3 to 30 colonies per drop of sample dispensed.

\section{Statistical Analysis}

Data were analyzed using the SAS procedure PROC MIXED (SAS Institute, 1996) as recommended by Wang and Goonewardene (2004) for the analysis of animal experiments with repeated measures. The effects of treatment, time (day for rumen $\mathrm{pH}$ and total VFA, or hour for SAA, Hp, and LPS data), and their interactions were considered fixed. Animal and interactions of other factors with animal were considered random. Data for ruminal LPS and total coliform counts were log transformed because of nonhomogeneous residual error. The most appropriate covariance structure relative to the hourly or daily measurements that were tested included simple, first-order ante dependence, unstructured covariance, compound symmetry, and first-order autoregressive (Wang and Goonewardene, 2004). Final mixed models were accepted only if the converge criteria was met, the estimated G matrix was positive definite, and the degrees of freedom were the same as those obtained by running the same model using the GLM procedure (SAS Institute, 1996). The covariance structure that resulted in the lowest value for the fit statistic was chosen (Wang and Goonewardene, 2004). Orthogonal contrasts were used to compare the all-forage diet with the $61 \%$ concentrate diet, and the $61 \%$ concentrate diet with the $76 \%$ concentrate diet for all variables measured. However, where a diurnal variation of a variable was of interest, and in the absence of a significant interaction, Tukey's multiple range test was used to separate means.

\section{RESULTS}

\section{DMI}

Dry matter intakes were, on average, $6.1 \pm 2.57,5.2$ \pm 2.27 , and $6.0 \pm 2.98 \mathrm{~kg}$ of $\mathrm{DM} / \mathrm{d}$ (mean $\pm \mathrm{SD}$ ) of $\mathrm{CH}$ for steers 1,2 , and 3 , respectively during wk 1 . Averaged across animals, DMI were 5.7, 5.8, 5.8, 5.9 , and $6.7 \mathrm{~kg}$ of $\mathrm{DM} / \mathrm{d}$, for concentrate inclusion levels of $0,21,41$, 61 , and $76 \%$ DM, respectively (Table 2). Dry matter intake for treatment 5 (76\% concentrate inclusion) was measured only during the days that SARA was induced. The steers did not consume all the WBP and $\mathrm{CH}$ offered, and the actual consumption of $\mathrm{CH}$ and WBP resulted in concentrate inclusions of 55 and $82 \%$ DM for steer 1, 74 and $86 \% \mathrm{DM}$ for steer 2, and 77\% DM on both 
Table 2. Intakes (mean \pm SD) of steers offered graded levels of wheat-barley concentrate and chopped hay during gradual stepwise adaptation to concentrate and subacute ruminal acidosis (SARA) induction

\begin{tabular}{llllll}
\hline & \multicolumn{5}{c}{ Treatment $^{1}$} \\
\cline { 2 - 6 } Intake & 1 & 2 & 3 & 4 & 5 \\
\hline Feed & & & & \\
$\quad$ Chopped hay, kg of DM/d & $5.7 \pm 2.5$ & $4.6 \pm 0.4$ & $3.4 \pm 0.3$ & $2.3 \pm 0.2$ & $1.6 \pm 0.4$ \\
$\quad \begin{array}{l}\text { Wheat-barley pellets, } \mathrm{kg} \text { of DM/d } \\
\quad \text { Total intake, kg of DM/d }\end{array}$ & $5.7 \pm 2.5$ & $5.8 \pm 0.1$ & $2.4 \pm 0.2$ & $3.6 \pm 0.3$ & $5.1 \pm 1.4$ \\
$\begin{array}{l}\text { Orts/d, \% of DM offered } \\
\begin{array}{l}\text { Average forage-to-concentrate } \\
\text { ratio of ingested feed }\end{array}\end{array}$ & 41 & 0 & $5.8 \pm 0.5$ & $5.9 \pm 0.5$ & $6.7 \pm 1.4$ \\
\hline
\end{tabular}

${ }^{1}$ Treatments 1 to 4 represent gradual adaptation to a high-concentrate diet, and treatment 5 represents the SARA induction model. Dry matter intakes for treatments 1 to 4 are the weekly averages, and DMI for treatment 5 is the average intake over the $2 \mathrm{~d}$ that SARA was induced in the 3 steers.

days for steer 3 . On average, $0.2 \mathrm{~kg}$ of $\mathrm{DM}$ of $\mathrm{CH}$ and 0.8 $\mathrm{kg}$ of DM of WBP that were offered were not consumed.

\section{Rumen pH and Ruminal LPS}

Average rumen $\mathrm{pH}$ tended to be lower $(P=0.06)$ when steers were on the $61 \%$ concentrate diet compared with the all-forage diet. Inducing SARA by feeding the $76 \%$ concentrate diet decreased $(P=0.04)$ the average rumen $\mathrm{pH}$ compared with that observed when steers were adapted to the $61 \%$ concentrate diet (Table 3). Compared with feeding the all-forage diet, feeding the $61 \%$ concentrate diet tended to increase $(P=0.07)$ the time with $\mathrm{pH}$ below 6 but did not affect the time with $\mathrm{pH}$ below 5.6. However, inducing SARA increased $(P=$ $0.003)$ the time with $\mathrm{pH}$ below 6 and also increased $(P=$ 0.02 ) the time with $\mathrm{pH}$ below 5.6 compared with the all-forage diet. The times with $\mathrm{pH} 6$ and $\mathrm{pH}$ below 5.6 did not differ between the 61 and $76 \%$ concentrate diets. The areas under the $\mathrm{pH} \times$ time curve for both the 5.6 and $6.0 \mathrm{pH}$ thresholds were not affected $(P>0.1)$ by stepwise adaptation to concentrate or by inducing SARA. Compared with the all-forage diet, the area un- der the $\mathrm{pH} \times$ time curve tended to be higher $(P=0.095)$ when SARA was induced (Table 3). Total VFA were measured to indicate changes in rumen $\mathrm{pH}$ and changes in fermentation patterns. The concentration of VFA was influenced by both treatment and time after feeding (Figure 1). Volatile fatty acid concentrations increased to peak around $1200 \mathrm{~h}$ during stepwise concentrate adaptation, but peaked around $1500 \mathrm{~h}$ when steers were fed the $76 \%$ concentrate diet to induce SARA.

Increasing the WBP concentrate from 0 to $61 \%$ increased $(P<0.0001)$ the ruminal LPS concentration. Inducing SARA after concentrate adaptation increased $(P=0.05)$ the ruminal LPS concentration compared with feeding the $61 \%$ concentrate diet. The ruminal LPS concentration increased curvilinearly when the amount of concentrate in the diet increased (Figure $2)$. There was also a significant $(P<0.0001)$ diurnal variation in LPS concentration due to the absence of a treatment $\times$ hour interaction; data were pooled across treatments to present ruminal LPS concentrations in samples collected at $0900,1200,1500$, and $2100 \mathrm{~h}$. The ruminal LPS concentration increased from $4.039 \log _{10}$

Table 3. Rumen $\mathrm{pH}$ variables of steers offered graded levels of wheat-barley concentrate and chopped hay during gradual stepwise adaptation to the concentrate and subacute ruminal acidosis (SARA) induction ${ }^{1}$

\begin{tabular}{|c|c|c|c|c|c|c|c|c|c|}
\hline \multirow[b]{2}{*}{ Rumen variable } & \multicolumn{5}{|c|}{ Treatment $^{2}$} & \multirow[b]{2}{*}{ SEM } & \multicolumn{3}{|c|}{$P$-value } \\
\hline & 1 & 2 & 3 & 4 & 5 & & Trt & Day $^{3}$ & Day $\times$ Trt \\
\hline Forage-to-concentrate ratio & 100:0 & $79: 21$ & $59: 41$ & $39: 61$ & $24: 76$ & & & & \\
\hline Average $\mathrm{pH}$ & $6.72^{\mathrm{a}}$ & $6.69^{\mathrm{a}}$ & $6.64^{\mathrm{a}}$ & $6.44^{\mathrm{a}}$ & $6.14^{\mathrm{b}}$ & 0.17 & 0.003 & 0.41 & 0.88 \\
\hline Time $<\mathrm{pH} 5.6, \mathrm{~min} / \mathrm{d}$ & $0^{\mathrm{b}}$ & $0^{\mathrm{b}}$ & $0^{\mathrm{b}}$ & $121^{\mathrm{ab}}$ & $219^{\mathrm{a}}$ & 61.6 & 0.069 & 0.71 & 0.99 \\
\hline Time $<\mathrm{pH} 6.0, \mathrm{~min} / \mathrm{d}$ & $22^{\mathrm{bc}}$ & $0^{c}$ & $10^{\mathrm{bc}}$ & $344^{\mathrm{ab}}$ & $600^{\mathrm{a}}$ & 119.3 & 0.007 & 0.78 & 0.30 \\
\hline Area $<\mathrm{pH} 5.6, \min \times \mathrm{pH} / \mathrm{d}$ & 0 & 0 & 0 & 17 & 38 & 15.2 & 0.34 & 0.23 & 0.68 \\
\hline Area $<\mathrm{pH} 6.0, \min \times \mathrm{pH} / \mathrm{d}$ & 1 & 0 & 1 & 101 & 216 & 73.4 & 0.20 & 0.38 & 0.65 \\
\hline
\end{tabular}

${ }^{\mathrm{a}-\mathrm{c}}$ Means with different superscripts within each row differ $(P \leq 0.05)$.

${ }^{1}$ Orthogonal contrasts were used for mean separation for significant treatment (Trt) effects.

${ }^{2}$ Treatments 1 to 4 represent gradual adaptation to a high-concentrate diet, and treatment 5 represents the SARA induction model.

${ }^{3} \mathrm{Rumen} \mathrm{pH}$ measurements were taken over $2 \mathrm{~d}$ for each treatment. 


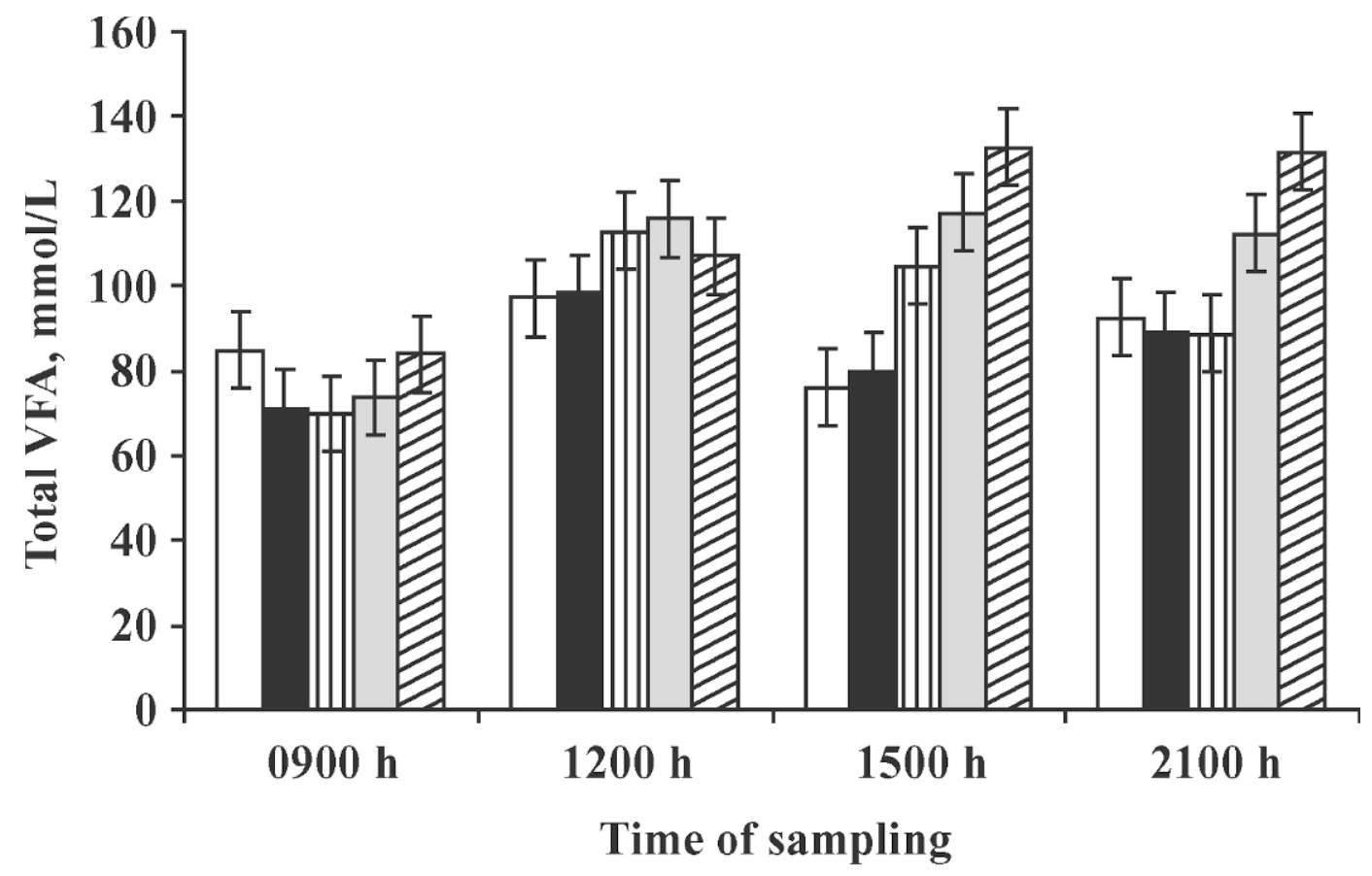

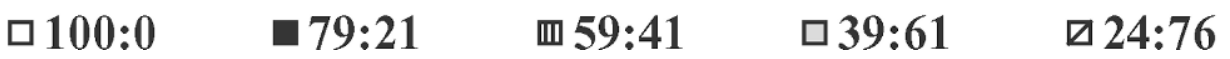

Figure 1. Total VFA concentration (mmol/L) in rumen fluid of steers offered graded levels of wheat-barley concentrate and chopped hay during gradual stepwise adaptation to the concentrate and subacute ruminal acidosis (SARA) induction. Error bars indicate SE. Dietary forage-to-concentrate $(\mathrm{F}: \mathrm{C})$ ratios $(\%)$ : treatment $1=100: 0$ diet; treatment $2=79: 21$ diet; treatment $3=59: 41$ diet; treatment $4=39: 61$ diet; and treatment $5=24: 76$ diet. The diet $\times$ time of sampling interaction was significant $(P<0.001)$. Rumen fluid samples were collected on $2 \mathrm{~d}$ during which steers were fed diets with graded levels of chopped hay and wheat-barley pellets.

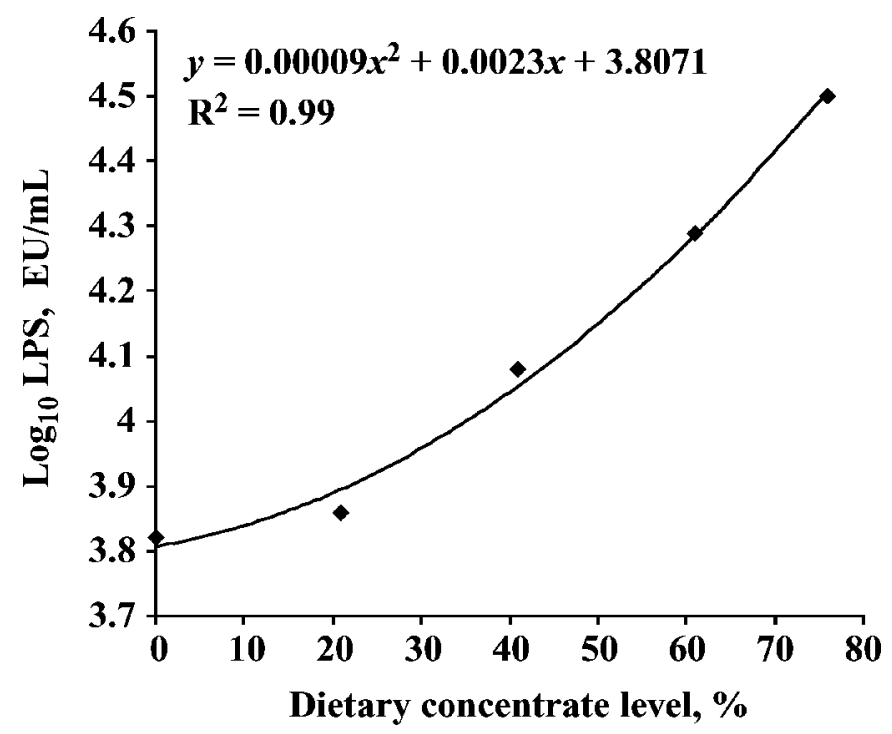

Figure 2. Relationship between ruminal LPS concentration $\left[\log _{10}\right.$ endotoxin units $(\mathrm{EU}) / \mathrm{mL}$ ] and dietary concentrate level in rumen fluid during gradual stepwise adaptation to the concentrate and subacute ruminal acidosis (SARA) induction. Linear and quadratic coefficients were significant $(P<0.0001$ and $P<0.0002$, respectively).
$\mathrm{EU} / \mathrm{mL}$ at $0900 \mathrm{~h}$ to a peak of $4.135 \log _{10} \mathrm{EU} / \mathrm{mL}$ at $1500 \mathrm{~h}$ (Figure 3).

\section{Total Coliform Counts}

Total coliform concentrations were $6.60,6.71,6.75$, 6.48 , and $6.62 \log _{10} \mathrm{cfu} / \mathrm{mL}$ in rumen fluid from steers fed diets containing $0,21,41,61$, and $76 \%$ concentrate, respectively (Figure 4). Although statistical analysis revealed a significant treatment effect $(P=0.03)$, none of the preplanned comparisons (i.e., all-forage diet vs. $61 \%$ concentrate diet, all-forage diet vs. $76 \%$ concentrate diet, or $61 \mathrm{vs.} 76 \%$ concentrate diet) differed from each other (Figure 4). However, graphical presentation of the data suggests a numerical increase in coliforms with increasing concentrate in the diet up to the $41 \%$ concentrate diet (Figure 4).

\section{Acute Phase Proteins}

The serum Hp concentration was higher $(P<0.01)$ in steers on the $61 \%$ concentrate diet compared with the all-forage diet. Inducing SARA after stepwise adaptation did not affect the Hp concentration. Haptoglobin 


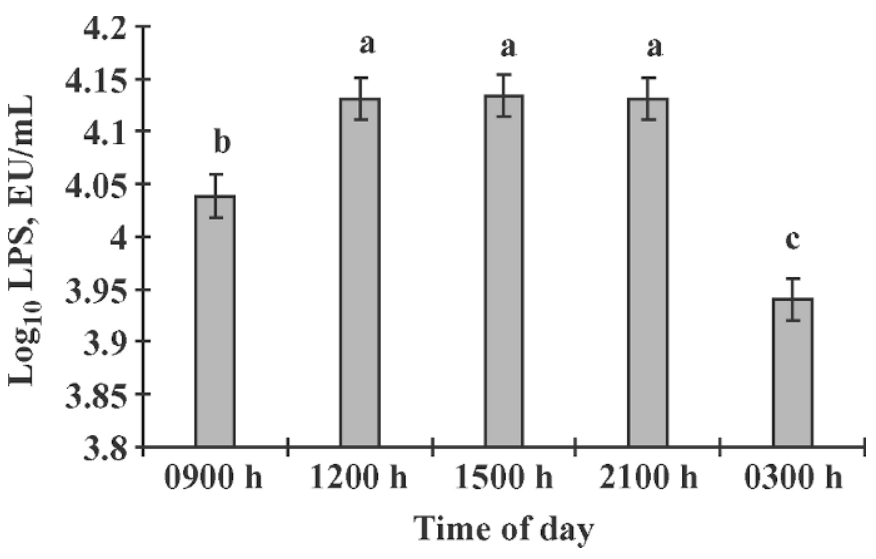

Figure 3. Diurnal changes in ruminal LPS concentrations $\left[\log _{10}\right.$ endotoxin units $(\mathrm{EU}) / \mathrm{mL}$ ] in steers offered graded levels of wheatbarley concentrate and chopped hay during gradual stepwise adaptation to the concentrate and subacute ruminal acidosis (SARA) induction. Error bars indicate SE. ${ }^{\text {a-c Tukey's multiple comparisons proce- }}$ dure was used to separate means, and significance was declared at the $5 \%$ level of significance.

concentrations were higher $(P=0.0008)$ in steers on both the 61 and $76 \%$ concentrate diets compared with the all-forage diet (Table 4). The Hp concentration increased from $0.53 \mathrm{mg} / \mathrm{mL}$ to 1.90 and $1.40 \mathrm{mg} / \mathrm{mL}$ when the steers were on the all-forage diet and on the 61 and $76 \%$ concentrate diets, respectively. Plasma concentrations of SAA tended to be elevated $(P=0.09)$ in steers on the $61 \%$ concentrate diet compared with the all-

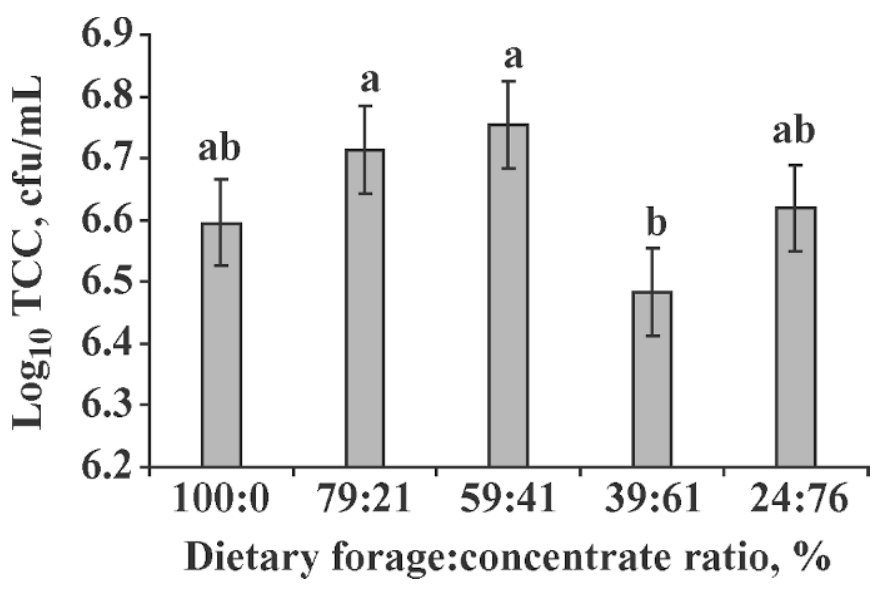

Figure 4. Total coliform counts (TCC; $\log _{10} \mathrm{cfu} / \mathrm{mL}$ ) in rumen fluid of steers offered graded levels of wheat-barley concentrate and chopped hay during gradual stepwise adaptation to concentrate and subacute ruminal acidosis (SARA) induction. Error bars indicate SE. Only samples collected at $0900 \mathrm{~h}$ during each of the two 24 -h sampling periods in each week were used in the data presented ${ }^{\mathrm{a}, \mathrm{b}}$ Orthogonal contrasts were used to compare counts in steers fed diets with different forage-to-concentrate ratios, and significance was declared at the $5 \%$ level of significance. forage diet and increased $(P<0.0001)$ further when the dietary concentrate increased to $76 \%$ (Table 4 ).

\section{DISCUSSION}

During adaptation to the $61 \%$ concentrate diet, the DM supplied to the steers was kept constant to minimize variability, because high-grain diets have been shown to result in erratic feeding patterns (Fulton et al., 1979). Similar to our earlier study (Gozho et al., 2005) and the study by Keunen et al. (2002), feed intake was not restricted during SARA induction, but the feeding protocol was designed to ensure high concentrate consumption by restricting access to $\mathrm{CH}$ to the first and last meal of the day. During SARA induction, steers consumed 0.8 to $1.0 \mathrm{~kg}$ more DM than during that attained in wk 1 to 4 . The higher intake and high concentrate inclusion in the diet in treatment 5 may have confounded the results. However, an earlier study in our laboratory showed that ruminal LPS concentrations, as well as SAA and Hp concentrations, increased when SARA was induced despite variable DMI (Gozho et al., 2005). Using a combination of feed restriction and complete withholding of feed, Brown et al. (2000) induced SARA in beef steers and were able to show that feed intake returned to normal by the third day after SARA was induced. In the present study, SARA was induced on Monday and Thursday of wk 5 so that if animals became anorexic because of SARA, there would be sufficient time for them to resume normal intake before the next SARA induction.

Rumen $\mathrm{pH}$ progressively decreased as the proportion of concentrate in the diet increased (Table 3). This is because the amount of nonstructural carbohydrates increased while the content of physically effective fiber in the diet decreased with each successive addition of concentrate. Subacute ruminal acidosis has been defined by rumen $\mathrm{pH}$ between 5.2 and 5.6 (Cooper and Klopfenstein, 1996). However, according to recent studies by Gozho et al. (2005), SARA should be defined as a depression in rumen $\mathrm{pH}$ so that cattle spend 3 or more hours with $\mathrm{pH}$ below 5.6. In the present study, SARA was induced only when the dietary concentrate increased to $76 \%$ DM. Time with $\mathrm{pH}$ below 5.6 was higher $(P=0.02)$ when the forage-to-concentrate ratio in the diet decreased from 100:0 to 24:76. In the present study, the steers spent an average of $219 \mathrm{~min} / \mathrm{d}$ with $\mathrm{pH}$ below 5.6 when they were on the $76 \%$ concentrate diet. In the rumen $\mathrm{pH}$ range that defines SARA, the decrease in $\mathrm{pH}$ is due to an increase total VFA concentration in the rumen (Krehbiel et al., 1995; Goad et al., 1998; Stone, 2004). In the present study, total VFA increased with each successive increment in concentrate in the diet (Figure 1). The time taken for the peak 
Table 4. Haptoglobin (Hp) and serum amyloid-A (SAA) concentrations in steers offered graded levels of wheat-barley concentrate and chopped hay during gradual stepwise adaptation to concentrate and subacute ruminal acidosis (SARA) induction ${ }^{1}$

\begin{tabular}{|c|c|c|c|c|c|c|c|c|c|}
\hline \multirow[b]{2}{*}{ Item } & \multicolumn{5}{|c|}{ Treatment $^{2}$} & \multirow[b]{2}{*}{ SEM } & \multicolumn{3}{|c|}{$P$-value } \\
\hline & 1 & 2 & 3 & 4 & 5 & & Trt & $\operatorname{Time}^{3}$ & Trt $\times$ time \\
\hline Forage-to-concentrate ratio & 100:0 & $79: 21$ & $59: 41$ & $39: 61$ & $24: 76$ & & & & \\
\hline $\mathrm{SAA}, \mu \mathrm{g} / \mathrm{mL}$ & $38^{\mathrm{b}}$ & $49^{\mathrm{b}}$ & $55^{\mathrm{b}}$ & $71^{\mathrm{b}}$ & $163^{\mathrm{a}}$ & 13.83 & $<0.0001$ & 0.23 & 0.44 \\
\hline
\end{tabular}

VFA concentration to be achieved differed among the diets, leading to a significant diet $\times$ time interaction for VFA concentration. This was probably because the level of concentrate in the diet differed during each week and also because the concentrate was offered in 2 meals during wk 5 compared with offering a mixed diet once in the morning as was done during wk 1 to 4 .

The concentration of ruminal LPS increased significantly starting with the $41 \%$ concentrate diet and continued to increase with subsequent additions of concentrate to the diet (Figure 2). There is a paucity of data on the effects of SARA on the ruminal LPS concentration. There also appear to be contradictions in the literature on the effect of acute acidosis on the LPS concentration. For example, Andersen and Jarlov (1990) induced acute acidosis in 2 adult Jersey cows and measured both rumen $\mathrm{pH}$ and ruminal LPS concentration. The LPS concentration decreased with decreasing rumen $\mathrm{pH}$. In another study, Andersen et al. (1994) observed relative increases in LPS concentration after grain engorgement to induce acute acidosis only in cows that had previously been adapted to a concentrate diet. The reductions in rumen $\mathrm{pH}$ below 5.0 that occurred when acute acidosis was induced in the previous studies probably resulted in bacteriological alterations that differed from those experienced when SARA was induced. Additionally, rumen $\mathrm{pH}$ was not measured and presented in a manner similar to that used in the current study, which makes it difficult to speculate on possible reasons for the differences. More recently, Gozho et al. (2005) showed that a $300 \%$ increase in ruminal LPS concentration occurred when SARA was induced in steers without prior adaptation to concentrate diets. In the present study, there was also an increase of about $300 \%$ in ruminal LPS when the steers were stepped up from an all-forage diet to a $61 \%$ concentrate diet. Furthermore, successive addition of concentrate in the diet caused ruminal LPS to increase at an increasing rate.

The chromogenic medium used for culturing coliforms is based on the ability of $E$. coli-specific glucuronidase to cleave a chromogenic substrate and produce purple colonies while a second chromogenic substrate is cleaved by galactosidase, an enzyme produced by the majority of coliforms, to produce pink colonies (Oxoid manual). The LPS from $E$. coli (O111:B4) is used as a reference standard endotoxin in determining LPS with the Limulus amoebocyte lysate assay. In the absence of any other group of bacteria that could be used to relate changes in ruminal LPS concentration to gramnegative bacteria, coliforms numbers were monitored during the course of the experiment. Total coliform concentrations for samples collected at $0900 \mathrm{~h}$ from wk 1 to 5 were used to determine the effects of stepwise concentrate adaptation on coliform numbers. Even though there was not a statistically significant difference in the coliform count between 100 and $59 \%$ forage, these changes closely mirrored the increase in LPS. One would not expect coliforms to be solely responsible for LPS in the rumen, and many other members of the Enterobacteriacea and other phyla of gram-negative bacteria that produce LPS are present in the rumen. The observation that the proportion of gram-negative bacteria in the rumen decreases when $\mathrm{pH}$ decreases, even though the numbers for both gram-positive and gram-negative species increase, has led some researchers to suggest that LPS in the rumen comes from either intact rapidly growing gram-negative bacteria, or from gram-negative bacterial death and lysis (Nagaraja et al., 1978). It has also been suggested that as much as $60 \%$ of LPS in the rumen may be released during bacterial growth (Andersen, 2000). During rapid growth, autolytic enzymes are required for bacterial cells to expand and grow, but excessive autolytic activity leads to bacterial cell lysis. Studies with Fibrobacter succinogenes showed that autolysis was 10 -fold higher in rapidly growing cells compared with cells in the stationary phase (Wells and Russell, 1996). It is possible that rumen $\mathrm{pH}$ conditions for some part of the day resulted in rapid growth of some gram-negative bacteria and that this contributed to increases in LPS in the rumen during concentrate adaptation and SARA induction. 
In a previous study, SAA and Hp concentrations increased when time with $\mathrm{pH}$ below 5.6 increased to more than $3 \mathrm{~h} / \mathrm{d}$ (Gozho et al., 2005). Increasing the proportion of WBP in the diet beyond $61 \%$ of DM activated an inflammatory response (Table 4). High inclusion rates of concentrate in the diet depressed rumen $\mathrm{pH}$ and may have compromised animal health, possibly by altering rumen permeability to substances such as LPS or through inflammation of the epithelial tissue of the digestive tract, resulting in increased LPS translocation into blood circulation because of a compromised digestive tract physical barrier. If LPS translocation is the main determinant of inflammation when SARA is induced, it is not clear how much LPS must be translocated into the bloodstream to increase the acute phase protein concentrations in peripheral circulation. Repeated episodes of SARA may lead to rumen papillae inflammation as well as hyperkeratosis of the rumen wall, which exacerbates the acidity in the rumen, leading to further damage of the rumen epithelium, pathogen infiltration, and abscessation of various organs in the body (Nocek, 1997; Kleen et al., 2003). This damage to rumen mucosal tissue may contribute to the observed inflammatory response in SARA-induced cattle.

The Hp concentration increased $(P=0.0008)$ when the 61 and $76 \%$ concentrate diets were fed. Haptoglobin concentrations have been shown to increase after experimentally induced inflammation (Conner et al., 1988), after trauma (Earley and Crowe, 2002), and also after experimental infections with bovine respiratory syncytial virus (Heegaard et al., 2000) and natural diseases (Alsemgeest et al., 1994). Serum amyloid-A concentrations increased when steers were on the $76 \%$ concentrate diet. These data suggest that a relationship between the occurrence of SARA and changes in the SAA concentration may be developed. However, this would only be possible in the absence of other acute phase stimulants such as mastitis, metritis in dairy cows, other tissue injury, or viral or bacterial infections that induce an inflammatory response (Petersen et al., 2004). Acute phase proteins are released from hepatocytes on stimulation by inflammation mediators, which include IL-1, IL-6, and tumor necrosis factor. These mediators are produced by tissue macrophages or blood monocytes at the site of injury or infection (Steel and Whitehead, 1994). The quantification of acute phase proteins in this study and in our earlier study (Gozho et al., 2005) indicate that SARA initiates an inflammatory response.

\section{CONCLUSIONS}

In this experiment, gradual stepwise adaptation to a $61 \%$ wheat-barley concentrate diet resulted in a $300 \%$ increase in the ruminal LPS concentration. Subsequent induction of SARA resulted in an additional $48 \%$ increase in ruminal LPS. Total coliform numbers in the rumen fluid were not affected by dietary concentrate or rumen $\mathrm{pH}$. Changes in SAA and Hp concentrations indicated that inflammation occurred when SARA was induced in the steers. These data show the importance of acute phase proteins in the early detection of SARA in the absence of overt signs. With wheat and barley as the main concentrate ingredients and hay as the main forage, the dietary forage-to-concentrate ratios of less than 39:61 appeared to decrease the rumen $\mathrm{pH}$ sufficiently to activate an inflammatory response. The data also suggest that the factors that determine the concentrations of ruminal LPS are still not clearly understood.

\section{ACKNOWLEDGMENTS}

The Natural Sciences and Engineering Research Council of Canada (NSERC) is sincerely thanked for funding the project (J. C. P.) and the Cyril L. AndersonRidley Canada Limited Graduate Fellowship in Animal Nutrition is acknowledged for financial support (G. N. G.). We also thank Dale Rosner and the staff at Glenlea Research Station and Robert Stuski for looking after the animals; Terri Garner, Akbar Nikkhah, Ehsan Khafipoor, and Sanjiv Bandari for technical assistance; and Gary Crow and Loreen Onischuk for help with statistical analyses.

\section{REFERENCES}

Alsemgeest, S. P., H. C. Kalsbeek, T. Wensing, J. P. Koeman, A. M. van Ederen, and E. Gruys. 1994. Concentrations of serum amyloid-A (SAA) and haptoglobin (HP) as parameters of inflammatory diseases in cattle. Vet. Q. 16:21-23.

Andersen, P. H. 2000. Endotoxicosis: Aspects of Relevance to Ruminal Acidosis. Dr. Vet. Sci. Thesis. The Royal Veterinary and Agricultural University, Copenhagen, Denmark.

Andersen, P. H., B. Bergelin, and K. A. Christensen. 1994. Effect of feeding regimen on concentration of free endotoxin in ruminal fluid of cattle. J. Anim. Sci. 72:487-491.

Andersen, P. H., and N. Jarlov. 1990. Investigation of the possible role of endotoxin, TXA2, PGI2 and PGE2 in experimentally induced rumen acidosis in cattle. Acta Vet. Scand. 31:27-38.

Brown, M. S., C. R. Krehbiel, M. L. Galyean, M. D. Remmenga, J. P. Peters, B. Hibbard, J. Robinson, and W. M. Moseley. 2000. Evaluation of models of acute and subacute acidosis on dry matter intake, ruminal fermentation, blood chemistry, and endocrine profiles of beef steers. J. Anim. Sci. 78:3155-3168.

Bryant, M. P. 1972. Commentary on the Hungate technique for culture of anaerobic bacteria. Am. J. Clin. Nutr. 25:1324-1328.

Conner, J. G., P. D. Eckersall, A. Wiseman, T. C. Aitchison, and T. A. Douglas. 1988. Bovine acute phase response following turpentine injection. Res. Vet. Sci. 44:82-88.

Cooper, R., and T. Klopfenstein. 1996. Effects of Rumensin and Feed Intake Variation on Ruminal pH: Update on Rumensin/Tylan/ Micotyl for the Professional Feedlot Consultant. Elanco Animal Health, Greenfield, IN.

Cooper, R. J., T. J. Klopfenstein, R. A. Stock, C. T. Milton, D. W. Herold, and J. C. Parrott. 1999. Effects of imposed feed intake 
variation on acidosis and performance of finishing steers. J. Anim. Sci. 77:1093-1099.

Counotte, G. H. M., R. A. Prins, R. H. A. M. Janssen, and M. J. A. deBie. 1981. Role of Megasphaera elsdenii in the fermentation of DL- $\left[2-{ }^{13} \mathrm{C}\right]$ lactate in the rumen of dairy cattle. Appl. Environ. Microbiol. 42:649-655.

Cumby, J. L., J. C. Plaizier, I. Kyriazakis, and B. W. McBride. 2001. Effect of subacute ruminal acidosis on the preference of cows for pellets containing sodium bicarbonate. Can. J. Anim. Sci. 81:149-152.

Dijkstra, J., J. A. N. Mills, and J. France. 2002. The role of dynamic modeling in understanding the microbial contribution to rumen function. Nutr. Res. Rev. 15:67-90.

Earley, B., and M. A. Crowe. 2002. Effects of ketoprofen alone or in combination with local anesthesia during the castration of bull calves on plasma cortisol, immunological and inflammatory response. J. Anim. Sci. 80:1044-1052.

Erwin, E. S., G. J. Marco, and E. M. Emery. 1961. Volatile fatty acids analysis of blood and rumen fluid by gas chromatography. J. Dairy Sci. 44:1768-1776.

Frampton, E. W., L. Restaino, and N. Blaszko. 1988. Evaluation of the $\beta$-glucuronidase substrate 5 -bromo-4-chloro-3-indolyl- $\beta$-Dglucuronide (XGLUC) in a 24-hour direct plating method for Escherichia coli. J. Food Prot. 51:402-404.

Fulton, W. R., T. J. Klopfenstein, and R. A. Britton. 1979. Adaptation to high concentrate diets by beef cattle. 1 . Adaptation to corn and wheat diets. J. Anim. Sci. 49:775-784.

Garrett, E. F., K. V. Nordlund, W. J. Goodger, and G. R. Oetzel. 1997. A cross-sectional field study investigating the effect of periparturient dietary management on ruminal $\mathrm{pH}$ in early lactation dairy cows. J. Dairy Sci. 80(Suppl. 1):169. (Abstr.)

Goad, D. W., C. L. Goad, and T. G. Nagaraja. 1998. Ruminal microbial and fermentative changes associated with experimentally induced subacute acidosis in steers. J. Anim. Sci. 76:234-241.

Gozho, N. G., J. C. Plaizier, D. O. Krause, A. D. Kennedy, and K. M. Wittenberg. 2005. Subacute ruminal acidosis induces ruminal lipopolysaccharide endotoxin release and triggers an inflammatory response. J. Dairy Sci. 88:1399-1403.

Heegaard, P. M. H., D. L. Godson, M. J. M. Toussaint, K. Tjørnehøj, L. E. Larsen, B. Viuff, and L. Rønsholt. 2000. The acute phase response of haptoglobin and serum amyloid A (SAA) in cattle undergoing experimental infection with bovine respiratory syncytial virus. Vet. Immunol. Immunopathol. 77:151-159.

Keunen, J. E., J. C. Plaizier, I. Kyriazakis, T. F. Duffield, T. M. Widowski, M. I. Lindinger, and B. W. McBride. 2002. Effects of a subacute ruminal acidosis model on the diet selection of dairy cows. J. Dairy Sci. 85:3304-3313.

Kleen, J. L., G. A. Hooijer, J. Rehage, and J. P. T. M. Noordhuizen. 2003. Subacute ruminal acidosis (SARA): A review. J. Vet. Med. A 50:406-414.
Krehbiel, C. R., R. A. Stock, D. H. Shain, C. J. Richards, G. A. Ham, R. A. McCoy, T. J. Klopfenstein, R. A. Britton, and R. P. Huffman. 1995. Effect of level and type of fat on subacute acidosis in cattle fed dry-rolled corn finishing diets. J. Anim. Sci. 73:2438-2446.

Lammers, B. P., D. R. Buckmaster, and A. J. Heinrichs. 1996. A simple method for the analysis of particle sizes of forages and total mixed rations. J. Dairy Sci. 79:922-928.

Levin, J., and F. B. Bang. 1964. A description of cellular coagulation in the Limulus. Bull. Johns Hopkins Hosp. 115:337-345.

Mackie, R. I., and F. M. C. Gilchrist. 1979. Changes in lactate-producing and lactate-utilizing bacteria in relation to $\mathrm{pH}$ in the rumen of sheep during stepwise adaptation to a high-concentrate diet. Appl. Environ. Microbiol. 38:422-430.

Mackie, R. I., F. M. C. Gilchrist, A. M. Roberts, P. E. Hannah, and H. M. Schwartz. 1978. Microbiological and chemical changes in the rumen during the stepwise adaptation of sheep to high concentrate diets. J. Agric. Sci. 90:241-254.

Nagaraja, T. G., E. E. Bartley, L. R. Fina, and H. D. Anthony. 1978. Relationship of rumen gram-negative bacteria and free endotoxin to lactic acidosis in cattle. J. Anim. Sci. 47:1329-1336.

Nocek, J. E. 1997. Bovine acidosis: Implications on laminitis. J. Dairy Sci. 80:1005-1028.

Nordlund, K. V., N. B. Cook, and G. R. Oetzel. 2004. Investigation strategies for laminitis problem herds. J. Dairy Sci. 87:E27- E35.

Nordlund, K. V., E. F. Garrett, and G. R. Oetzel. 1995. Herd-based rumenocentesis: A clinical approach to the diagnosis of subacute rumen acidosis. Compend. Contin. Educ. Pract. Vet. Food Anim. $17: \mathrm{s} 48-\mathrm{s} 56$.

Oetzel, G. R., K. V. Nordlund, and E. F. Garett. 1999. Effect of ruminal $\mathrm{pH}$ and stage of lactation on ruminal lactate concentration in dairy cows. J. Dairy Sci. 82(Suppl. 1):35.

Owens, F. N., D. S. Secrist, W. J. Hill, and D. R. Gill. 1998. Acidosis in cattle: A review. J. Anim. Sci. 76:275-286.

Petersen, H. H., J. P. Nielsen, and P. M. H. Heegaard. 2004. Application of acute phase protein measurements in veterinary clinical chemistry. Vet. Res. 35:163-187.

SAS Institute. 1996. SAS System for Mixed Models. 4th ed. SAS Inst., Inc., Cary NC.

Steel, D. M., and A. S. Whitehead. 1994. The major acute phase reactants: C-reactive protein, serum amyloid P component and serum amyloid A protein. Immunol. Today 15:81-88.

Stone, W. C. 2004. Nutritional approaches to minimize subacute ruminal acidosis and laminitis in dairy cattle. J. Dairy Sci. 87(E. Suppl.):E13-E26.

Wang, Z., and L. A. Goonewardene. 2004. The use of MIXED models in the analysis of animal experiments with repeated measures data. Can. J. Anim. Sci. 84:1-11.

Wells, J. E., and J. Russell. 1996. The effect of growth and starvation on the lysis of the ruminal cellulolytic bacterium Fibrobacter succinogenes. Appl. Environ. Microbiol. 62:1342-1346. 